\title{
Front Matter: Volume 8256
}

, "Front Matter: Volume 8256," Proc. SPIE 8256, Physics, Simulation, and Photonic Engineering of Photovoltaic Devices, 825601 (2 April 2012); doi: 10.1117/12.931050

SPIE. Event: SPIE OPTO, 2012, San Francisco, California, United States 


\title{
PRO CEEDINGS OF SPIE
}

\section{Physics, Simulation, and Photonic Engineering of Photovoltaic Devices}

\author{
Alexandre Freundlic $h$ \\ J ean-Francois F. Guillemoles \\ Editors
}

\section{3-26 J anuary 2012}

San Franc isco, Califomia, United States

Sponsored and Published by

SPIE 
The papers included in this volume were part of the technical conference cited on the cover and title page. Papers were selected and subject to review by the editors and conference program committee. Some conference presentations may not be available for publication. The papers published in these proceedings reflect the work and thoughts of the authors and are published herein as submitted. The publisher is not responsible for the validity of the information or for any outcomes resulting from reliance thereon.

Please use the following format to cite material from this book:

Author(s), "Title of Paper," in Physics, Simulation, and Photonic Engineening of Photovoltaic Devices, edited by Alexandre Freundlich, J ean-Francois F. Guillemoles, Proceedings of SPIE Vol. 8256 (SPIE, Bellingham, WA, 2012) Artic le CID Number.

ISSN 0277-786X

ISBN 9780819488992

Published by

SPIE

P.O. Box 10, Bellingham, Wa shington 98227-0010 USA

Telephone +1 3606763290 (Pacific Time)· Fax +1 3606471445

SPIE.org

Copyright $\odot 2012$, Society of Photo-Optic al Instrumentation Engineers

Copying of material in this book for intemal or personal use, or for the intemal or personal use of specific clients, beyond the fair use provisions granted by the U.S. Copyright Law is authorized by SPIE subject to payment of copying fees. The Transactional Reporting Service base fee for this volume is $\$ 18.00$ per article (or portion thereof), which should be paid directly to the Copyright Clearance Center (CCC), 222 Rosewood Drive, Danvers, MA 01923. Payment may also be made electronically through CCC Online at copyright.com. Other copying for republication, resale, advertising or promotion, or any form of systematic or multiple reproduction of any material in this book is prohibited except with permission in writing from the publisher. The CCC fee code is $0277-786 \mathrm{X} / 12 / \$ 18.00$.

Printed in the United States of America.

Public ation of record for individual papers is online in the SPIE Digital Library.

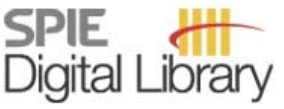

SPIEDigitallibrary.org

Paper Numbering: Proceedings of SPIE follow an e-First public ation model, with papers published first online and then in print and on CD-ROM. Papers are published as they a re submitted and meet public ation criteria. A unique, consistent, permanent citation identifier (CID) number is assigned to each artic le at the time of the first public ation. Utilization of CIDs a llows artic les to be fully citable as soon as they are published online, and connects the same identifier to all online, print, and electronic versions of the public ation. SPIE uses a six-digit CID artic le numbering system in which:

- The first four digits correspond to the SPIE volume number.

- The last two digits indicate publication order within the volume using a Base 36 numbering system employing both numera ls and letters. These two-number sets start with $00,01,02,03,04$, $05,06,07,08,09,0 A, 0 B \ldots$ OZ, followed by 10-1Z, 20-2Z, etc.

The CID numberappears on each page of the manuscript. The complete citation is used on the first page, and an abbreviated version on subsequent pages. Numbers in the index correspond to the last two digits of the six-digit CID number. 


\section{Contents}

ix Conference Committee

xi Introduction

xiii Spinoptics: Spin degeneracy removal in nanostructures (Plenary Paper) [8269-100]

V. Kleiner, N. Shitrit, E. Hasman, Technion-Israel Institute of Technology (Israel)

\section{SESSION 1 ADVANCED LIGHT MANAGEMENT AND SPECTRAL SHAPING}

825602 Increasing upconversion by metal and dielectric nanostructures (Invited Paper) [8256-01] J. C. Goldschmidt, S. Fischer, H. Steinkemper, B. Herter, T. Rist, S. Wolf, B. Bläsi, Fraunhofer Institute for Solar Energy Systems ISE (Germany); F. Hallermann, G. von Plessen, RWTH Aachen Univ. (Germany); K. W. Krämer, D. Biner, Univ. Bern (Switzerland); M. Hermle, Fraunhofer Institute for Solar Energy Systems ISE (Germany)

825603 Simulations of solar cell absorption enhancement using resonant modes of a nanosphere array (Invited Paper, Green Photonics Award) [8256-02]

J. Grandidier, M. G. Deceglie, D. M. Callahan, H. A. Atwater, California Institute of Technology (United States)

825606 Exact field solution to guided wave propagation in lossy thin films [8256-04] J. R. Nagel, S. Blair, M. A. Scarpulla, The Univ. of Utah (United States)

\section{SESSION 2 PHOTONIC AND PLASMONICS DESIGNS FOR PHOTOVOLTAICS}

825608 Plasmonic enhancement of up-conversion in ultrathin layers [8256-06] C. Andriamiadamanana, Institut de Recherche et Développement sur l'Energie Photovoltaïque (France) and Lab. of Chemistry of Condensed Materials, CNRS (France); A. Ferrier, Lab. of Chemistry of Condensed Materials, CNRS (France); L. Lombez, A.-L. Joudrier, N. Naghavi, Institut de Recherche et Développement sur l'Energie Photovoltaïque (France); P. Ghenuche, N. Bardou, J.-L. Pelouard, S. Collin, Lab. of Chemistry of Condensed Materials, CNRS (France); F. Pellé, Ecole Nationale Supérieure de Chimie de Paris (France); J.-F. Guillemoles, Institut de Recherche et Développement sur l'Energie Photovoltaïque (France)

825609 Improved efficiency for nanopillar array of c-Si photovoltaic by down-conversion and anti-reflection of quantum dots [8256-07]

C.-C. Lin, H.-C. Chen, H.-V. Han, Y.-L. Tsai, C.-H. Chang, M.-A. Tsai, H.-C. Kuo, P. Yu, National Chiao Tung Univ. (Taiwan)

$8256 \mathrm{OA}$ Scattering analysis of the indium-tin-oxide (ITO) nanowhiskers on ITO film substrate for thin film solar cell [8256-08]

H.-W. Liu, C.-H. Chang, C.-C. Lin, P. Yu, National Chiao Tung Univ. (Taiwan) 
SESSION 3 QUANTUM WELL AND SUPERLATTICE SOLAR CELLS

8256 OB Improving photo-generated carrier escape in quantum well solar cells (Invited Paper) [8256-09]

A. Alemu, A. Freundlich, Univ. of Houston (United States)

8256 OC Exploring the radiative limits of dark current operation in InGaAs quantum well solar cells (Invited Paper) [8256-10]

R. E. Welser, Magnolia Solar, Inc. (United States)

8256 OD Exploring the potential of quantum wells for efficiency enhancement in photovoltaic cells [8256-11]

M. Sugiyama, Y. Wang, H. Fujii, H. Sodabanlu, Y. Wen, K. Watanabe, Y. Nakano, The Univ. of Tokyo (Japan)

SESSION 4 QUANTUM DOT BASED SOLAR CELLS

8256 OG Photovoltaic properties of silicon nanocrystals in silicon carbide [8256-14]

P. Löper, A. Witzky, Fraunhofer-Institut für Solare Energiesysteme (Germany); A. Hartel,

S. Gutsch, D. Hiller, Albert-Ludwigs-Univ. Freiburg (Germany); J. C. Goldschmidt, S. Janz, S. W. Glunz, Fraunhofer-Institut für Solare Energiesysteme (Germany); M. Zacharias, Albert-Ludwigs-Univ. Freiburg (Germany)

8256 Ol Numerical simulation of QD-intermediate band solar cells: effect of dot size on performance [8256-16]

T. Bald, A. Fedoseyev, CFD Research Corp. (United States)

\section{SESSION 5 NOVEL THIN FILM MATERIALS AND DEVICES}

8256 OK $\quad \mathrm{Cu}(\mathrm{In}, \mathrm{Ga}) \mathrm{Se}_{2}$ photovoltaic microcells for high efficiency and low material usage [8256-18] M. Paire, Institut de Recherche et Développement sur l'Energie Photovoltaïque (France) and IRDEP, CNRS (France) and Ecole Nationale Supérieure de Chimie de Paris (France) and Univ. Pierre et Marie Curie (France); L. Lombez, F. Donsanti, M. Jubault, Institut de Recherche et Développement sur l'Energie Photovoltaïque (France) and IRDEP, CNRS (France) and Ecole Nationale Supérieure de Chimie de Paris (France); N. Péré-Laperne, S. Collin, Lab. de Photonique et de Nanostructures, CNRS (France); A. Perona, A. Dollet, Lab. de Procédés Matériaux et Energie Solaire, CNRS (France); J.-L. Pelouard, Lab. de Photonique et de Nanostructures, CNRS (France); D. Lincot, J.-F. Guillemoles, Institut de Recherche et Développement sur l'Energie Photovoltaïque (France) and IRDEP, CNRS (France) and Ecole Nationale Supérieure de Chimie de Paris (France)

8256 OM Optimal optical designs for planar GaAs single-junction solar cells with textured and reflective surfaces [8256-20]

S. Liu, D. Ding, S. R. Johnson, Y.-H. Zhang, Arizona State Univ. (United States) 
8256 OP Device simulation of intermediate band solar cells [8256-23]

K. Yoshida, Y. Okada, The Univ. of Tokyo (Japan); N. Sano, Univ. of Tsukuba (Japan)

$8256 \mathrm{OQ}$ The thermodynamic limits of tandem photovoltaic devices with intermediate band [8256-28]

J. Lee, C. B. Honsberg, Arizona State Univ. (United States)

\section{SESSION 7 ADVANCED TANDEM SOLAR CELLS}

8256 OR Spectrum-optimized Si-based III-V multijunction photovoltaics (Invited Paper) [8256-25] T. J. Grassman, A. M. Carlin, J. Grandal, C. Ratcliff, L. Yang, M. J. Mills, S. A. Ringel, The Ohio State Univ. (United States)

8256 OS Simulation of novel InAlAsSb solar cells [8256-26]

M. P. Lumb, U.S. Naval Research Lab. (United States) and The George Washington Univ. (United States); M. Gonzalez, U.S. Naval Research Lab. (United States) and Sotera Defence Solutions (United States); I. Vurgaftman, J. R. Meyer, J. Abell, M. Yakes, U.S. Naval Research Lab. (United States); R. Hoheisel, U.S. Naval Research Lab. (United States) and The George Washington Univ. (United States); J. G. Tischler, P. P. Jenkins, U.S. Naval Research Lab. (United States); P. N. Stavrinou, M. Fuhrer, N. J. Ekins-Daukes, Imperial College London (United Kingdom); R. J. Walters, U.S. Naval Research Lab. (United States)

8256 OT Two-dimensional modeling of CdZnTe/Si based dual and triple junction solar cells [8256-27] Y. G. Xiao, Z. Q. Li, M. Lestrade, Z. M. S. Li, Crosslight Software Inc. (Canada)

\section{SESSION 8 CARRIER RELAXATIONS AND HOT CARRIER SOLAR CELLS}

8256 OW Modeling carrier relaxation in hot carrier solar cells (Invited Paper) [8256-30]

S. M. Goodnick, C. Honsberg, Arizona State Univ. (United States)

$82560 X$ InGaAs/GaAsP quantum wells for hot carrier solar cells [8256-31]

L. C. Hirst, M. Fürher, D. J. Farrell, Imperial College London (United Kingdom); A. Le Bris, J.-F. Guillemoles, Institut de Recherche et Développement sur l'Energie Photovoltaïque (France); M. J. Y. Tayebjee, R. Clady, T. W. Schmidt, The Univ. of Sydney (Australia); M. Sugiyama, Y. Wang, H. Fujii, The Univ. of Tokyo (Japan); N. J. Ekins-Daukes, Imperial College London (United Kingdom)

\section{SESSION 9 NANOSTRUCTURES AND EMERGING PHOTOVOLTAIC APPROACHES}

$82560 Z$ Hot carrier cells: an example of third generation photovoltaics (Keynote Paper) [8256-33] G. Conibeer, The Univ. of New South Wales (Australia)

825610 Multiple exciton generation in PbSe nanorods [8256-34] P. D. Cunningham, J. E. Boercker, E. E. Foos, U.S. Naval Research Lab. (United States); M. P. Lumb, U.S. Naval Research Lab. (United States) and The George Washington Univ. (United States); A. R. Smith, J. G. Tischler, J. S. Melinger, U.S. Naval Research Lab. (United States) 
825613 Spectroscopic ellipsometry: metrology for photovoltaics from the nanoscale to gigawatts (Invited Paper) [8256-37]

S. Marsillac, Old Dominion Univ. (United States); R. W. Collins, The Univ. of Toledo (United States)

825614 Characterization of solar cells using electroluminescence and photoluminescence hyperspectral images (Invited Paper) [8256-38]

A. Delamarre, L. Lombez, J. F. Guillemoles, Institut de Recherche et Développement sur I'Energie Photovoltaïque, CNRS, Chimie ParisTech (France)

825615 Spectroscopic analysis of InAs quantum dot solar cells [8256-39]

S. J. Polly, Rochester Institute of Technology (United States); C. G. Bailey, U.S. Naval Research Lab. (United States); Z. S. Bittner, Y. Dai, E. G. Fernandez, S. M. Hubbard, Rochester Institute of Technology (United States)

825616 A novel method to eliminate the measurement artifacts of external quantum efficiency of multi-junction solar cells caused by the shunt effect [8256-40]

J.-J. Li, S. H. Lim, Y.-H. Zhang, Arizona State Univ. (United States)

\section{SESSION 11 ADVANCED LIGHT CONCENTRATION AND LIGHT TRAPPING FOR PHOTOVOLTAICS}

825617 Toward high efficiency ultra-thin CIGSe based solar cells using light management techniques (Invited Paper) [8256-41]

N. Naghavi, Z. Jehl, F. Donsanti, J.-F. Guillemoles, Institut de Recherche et Développement sur l'Energie Photovoltaïque, CNRS, Chimie-Paris Tech (France); I. Gérard, M. Bouttemy, A. Etcheberry, Institut Lavoisier de Versailles, CNRS, Univ. de Versailles Saint-Quentin-en Yvelines (France); J.-L. Pelouard, S. Collin, C. Colin, N. Péré-Laperne, Lab. de Photonique et de Nanostructures, CNRS (France); N. Dahan, J.-J. Greffet, Institut d'Optique, CNRS, Campus Polytechnique (France); B. Morel, Z. Djebbour, Lab. de Génie Électrique de Paris, CNRS, Univ. Pierre et Marie Curie Univ. Paris-Sud 11 (France); A. Darga, Lab. de Génie Électrique de Paris, CNRS, Univ. Pierre et Marie Curie Univ. Paris-Sud 11 (United States); D. Mencaraglia, Lab. de Génie Électrique de Paris, CNRS, Univ. Pierre et Marie Curie Univ. Paris-Sud 11 (France); G. Voorwinden, B. Dimmler, Wuerth Elektronik Research GmbH (Germany); M. Powalla, Zentrum für Sonnenenergie- und Wasserstoff-Forschung (Germany); D. Lincot, Institut de Recherche et Développement sur l'Energie Photovoltaïque, CNRS, Chimie-Paris Tech (France)

825618 Trackfree planar solar concentrator system [8256-42]

V. Zagolla, C. Moser, École Polytechnique Fédérale de Lausanne (Switzerland)

825619 A cascadable circular concentrator with parallel compressed structure for increasing the energy density [8256-43]

N.-L. Ku, Y.-Y. Chen, W.-C. Hsieh, A. J.-W. Whang, National Taiwan Univ. of Science and Technology (Taiwan) 
8256 1A Minimizing solar cell reflection loss through surface texturing and implementation of 1D and 2D subwavelength dielectric gratings [8256-44]

W. Wang, A. Mehrotra, A. Alemu, A. Freundlich, Univ. of Houston (United States)

SESSION 12 EPITAXY AND CHARACTERIZATION OF III-V PHOTOVOLTAIC MATERIALS

8256 1B Interface quality enhancement of the epitaxial regrowth process for nipi photovoltaic devices [8256-45]

M. A. Slocum, D. V. Forbes, S. M. Hubbard, Rochester Institute of Technology (United States)

8256 1C The role of Sb compositions on the properties of InAs/GaAsSb quantum dots (QDs) [8256-68] K.-Y. Ban, Arizona State Univ. (United States); S. P. Bremner, The Univ. of New South Wales (Australia); D. Kuciauskas, National Renewable Energy Lab. (United States); S. N. Dahal, C. B. Honsberg, Arizona State Univ. (United States)

8256 ID Characteristics of bulk InGaAsN and InGaAsSbN materials grown by metal organic vapor phase epitaxy (MOVPE) for solar cell application [8256-47]

T.-W. Kim, T. J. Garrod, Univ. of Wisconsin-Madison (United States); K. Kim, J. Lee, Ajou Univ. (Korea, Republic of); L. J. Mawst, T. F. Kuech, Univ. of Wisconsin-Madison (United States);

S. D. LaLumondiere, Y. Sin, W. T. Lotshaw, S. C. Moss, The Aerospace Corp. (United States)

8256 IE Dilute nitride GalnNAs and GalnNAsSb for solar cell applications [8256-48]

S. L. Tan, W. M. Soong, The Univ. of Sheffield (United Kingdom); M. J. Steer, Univ. of Glasgow (United Kingdom); S. Zhang, J. S. Ng, J. P. R. David, The Univ. of Sheffield (United Kingdom)

$8256 \mathrm{IF}$ Intersubband and intrasubband transition in InGaN quantum dot for solar cell application [8256-49]

K.-C. Wang, Y.-R. WU, National Taiwan Univ. (Taiwan)

\section{SESSION 13 SPACE PHOTOVOLTAICS}

8256 IG Advanced photovoltaic development at Air Force Research Laboratory (Keynote Paper) [8256-50]

D. M. Wilt, Air Force Research Lab. (United States)

$8256 \mathrm{1H}$ Modeling of defect-tolerant thin multi-junction solar cells for space application [8256-51] A. Mehrotra, A. Alemu, A. Freundlich, Univ. of Houston (United States)

$825611 \quad$ Radiation effects on quantum dot enhanced solar cells [8256-52]

C. Kerestes, D. Forbes, C. G. Bailey, Rochester Institute of Technology (United States); J. Spann, B. Richards, P. Sharps, Emcore Photovoltaics (United States); S. Hubbard, Rochester Institute of Technology (United States) 
8256 1K Photonic crystals for improving light absorption in organic solar cells (Invited Paper) [8256-54]

D. Duché, L. Escoubas, J.-J. Simon, Institut Matériaux Microélectronique Nanosciences de Provence, CNRS, Aix-Marseille Univ. (France); C. Gourgon, C. Masclaux, CEA-LETI (France); Ph. Torchio, J. Le Rouzo, F. Flory, Institut Matériaux Microélectronique Nanosciences de Provence, CNRS, Aix-Marseille Univ. (France)

8256 IL Resonance energy transfer from PbS colloidal quantum dots to bulk silicon: the road to hybrid photovoltaics [8256-55]

P. Andreakou, M. Brossard, Univ. of Southampton (United Kingdom); M. Bernechea,

G. Konstantatos, ICFO - Institut de Ciències Fotòniques (Spain); P. Lagoudakis, Univ. of Southampton (United Kingdom)

825610 Full device analysis of novel metamaterial coated PN and MIS solar cells using numerical methods [8256-57]

I. Mandel, The City College of the City Univ. of New York (United States); J. N. Gollub,

C. Sarantos, Phoebus Optoelectronics, LLC (United States); N. Pishbin, D. T. Crouse, The City College of the City Univ. of New York (United States)

\section{SESSION 15 POSTER SESSION}

$82561 Q \quad$ Energy converting material for solar cell application [8256-59]

M. Pokhrel, G. A. Kumar, D. K. Sardar, The Univ. of Texas at San Antonio (United States)

8256 IV Dynamic thermal analysis of a concentrated photovoltaic system [8256-64]

J. T. Avrett II, S. C. Cain, M. Pochet, Air Force Institute of Technology (United States)

8256 1X Analysis of radiation hardness and subcell I-V characteristics of GalnP/GaAs/Ge solar cells using electroluminescence measurements [8256-66]

R. Hoheisel, George Washington Univ. (United States) and Naval Research Lab. (United States); S. Messenger, D. Scheiman, P. P. Jenkins, R. J. Walters, Naval Research Lab. (United States)

825612 Optical simulation and fabrication of periodic triangular gratings for the enhancement of photovoltaic solar panels [8256-69]

R. Dey, E. V. Bordatchev, M. Tauhiduzzaman, H. Reshef, National Research Council Canada (Canada)

Author Index 


\title{
Conference Committee
}

\author{
Symposium Chair
}

Klaus P. Streubel, OSRAM GmbH (Germany)

Symposium Cochairs

David L. Andrews, University of East Anglia Norwich (United Kingdom) Liang-Chy Chien, Kent State University (United States)

Program Track Chair

James G. Grote, Air Force Research Laboratory (United States)

\section{Conference Chairs}

Alexandre Freundlich, University of Houston (United States)

Jean-Francois F. Guillemoles, Institut de Recherche et

Développement sur l'Energie Photovoltaïque (France)

Program Committee

Harry A. Atwater, California Institute of Technology (United States)

Sheila G. Bailey, NASA Glenn Research Center (United States)

Nicholas J. Ekins-Daukes, Imperial College London (United Kingdom)

Christiana B. Honsberg, Arizona State University (United States)

Seth M. Hubbard, Rochester Institute of Technology (United States)

Daniel Lincot, Ecole Nationale Supérieure de Chimie de Paris (France)

Antonio Marti, Universidad Politécnica de Madrid (Spain)

Marek Osinski, The University of New Mexico (United States)

Mike Scarpulla, The University of Utah (United States)

Masakazu Sugiyama, The University of Tokyo (Japan)

Robert J. Walters, U.S. Naval Research Laboratory (United States)

Peichen Yu, National Chiao Tung University (Taiwan)

Session Chairs

1 Advanced Light Management and Spectral Shaping

Gavin J. Conibeer, The University of New South Wales (Australia)

2 Photonic and Plasmonics Designs for Photovoltaics

Jean-Francois Guillemoles, Institut de Recherche et Développement sur l'Energie Photovoltaïque (France) 
3 Quantum Well and Superlattice Solar Cells

Seth M. Hubbard, Rochester Institute of Technology (United States)

4 Quantum Dot Based Solar Cells

Masakazu Sugiyama, The University of Tokyo (Japan)

$5 \quad$ Novel Thin Film Materials and Devices

Alexandre Freundlich, University of Houston (United States)

$6 \quad$ Intermediate Band Solar Cells

Olivier Durand, Institut National des Sciences Appliquées de Rennes (France)

$7 \quad$ Advanced Tandem Solar Cells

David Wilt, Air Force Research Laboratory (United States)

8 Carrier Relaxations and Hot Carrier Solar Cells

Gavin J. Conibeer, The University of New South Wales (Australia)

$9 \quad$ Nanostructures and Emerging Photovoltaic Approaches

Stephen M. Goodnick, Arizona State University (United States)

10 Advanced Device Characterization

Marek Osinski, The University of New Mexico (United States)

11 Advanced Light Concentration and Light Trapping for Photovoltaics Peichen Yu, National Chiao Tung University (Taiwan)

12 Epitaxy and Characterization of III-V Photovoltaic Materials

Christopher Kerestes, Rochester Institute of Technology (United States)

13 Space Photovoltaics

Robert J. Walters, U.S. Naval Research Laboratory (United States)

14 Hybrid Photovoltaic Approaches

Alexandre Freundlich, University of Houston (United States)

Jean-Francois Guillemoles, Institut de Recherche et Développement sur l'Energie Photovoltaïque (France) 


\section{Introduction}

Minimizing anthropogenic alterations of the world climate calls for the deployment of tens of terawatt of carbon-free renewable power generation resources, and solar photovoltaics (PV) has been recognized as a promising technology to help us meet these targets in a sustainable manner. Boosted by regulatory incentives, the PV industry is experiencing a strong growth and a significant influx of capital investment. Recent advances in solar cells and, in particular, in inexpensive thin films and concentrator PV devices, together with the growing penetration of PV into the energy markets, continue to drive down the cost of solar electricity generation. Today the production cost of the kwh in many applications approaches the retail price of electricity generated by traditional means (fossil fuels). However, in order for PV to become a major component of the global renewable energy portfolio, a nearly two-to-three-fold further cost reduction is needed. Such a cost reduction would require transformative technological breakthroughs that would significantly enhance the efficiency and/or simplicity of PV modules.

Within the framework of feeding into the innovation pipeline needed to the development of revolutionary and practically viable high efficiency and costeffective PV technologies, this first edition of the conference attempted to capture recent advances in the modeling and application of novel photonic engineering approaches, as well as in the understanding of the physics at play for the next generation of PV devices. The conference provided an interdisciplinary forum that aimed at enhancing interactions between physicists, photonic engineers and photovoltaic device specialists, at both the experimental and theoretical levels.

Theoretical and experimental papers presented at the conference highlighted recent advances in basic material/device physics, simulation, demonstration and optimization of:

- Advanced light management concepts and architectures, including new approaches to spectral engineering, light concentration, surface texturing, and light trapping (i.e., plasmonics nano-cavities, micro/nanoengineered ARs, track-free nano-engineered concentrators), as well as synergistic hybrid/multifunctional designs.

- Non-conventional PV converters, addressing the application of advanced photonics to enable unique conversion mechanisms. Presenters also provided an in-depth discussion of the fundamental aspects and recent developments in the demonstration of advanced quantum confined or nanostructured concepts, intermediate band concepts, multiple-excitongenerations, and hot-carrier effects. Also, particular focus was placed on deciphering the science at play in photo-generation, recombination, and 
carrier transport in quantum well/quantum dot, wire and superlattice devices.

- Advanced single- and multi-junction materials and devices leveraging on innovative materials or/and photonic architectures. In particular, several presentations focused on the simulation or/and demonstration of the application of cross-cutting photonic engineering approaches for enhancing the performance, reliability and functionality of thin film and multi-junction devices. Several presentations dealt with development of predictive simulation tools to optimize and enhance the defect tolerance (dislocations, radiation defects, etc.) of solar cells for space and terrestrial applications, as well as recent inroads in identifying and realizing novel more effective PV absorbers.

During and post conference, we received much positive feedback and encouragement from attendees and presenters. We are truly humbled by the experience, and hope that all attendees enjoyed the conference as much as we did. Of course, the primary ingredient for a successful technical conference is the quality of the work presented by the contributors, and, to this end, we would like to thank all the contributors for the quality of their presentations. We would like also to express our gratitude to all keynote and invited speakers for presenting exceptional overviews and igniting thought-provoking discussions. We would like also to congratulate Jonathan Grandidier and his coworkers from Caltech, as their work presented in our conference was this year's winner of the "Green Photonics Award for Renewable Energy Generation: Fusion and Photovoltaics." We are grateful to the committee members and session chairs, as their support and dedication before and during the event had a significant impact on the outcome and success of the meeting. We would like also to acknowledge the SPIE support staff for their invaluable help.

\section{Alexandre Freundlich Jean-Francois F. Guillemoles}

